\title{
Skinner and Feyerabend on the Method and the Role of Science in a Free Society
}

\author{
César Antonio Alves da Rocha ${ }^{\mathbf{1}}$ \\ Universidade Federal de São Carlos, São Carlos, SP, Brazil
}

\begin{abstract}
B. F. Skinner's work encompasses epistemological concerns, including discussions about methodology and truth criteria, along with political and social ones, concerning the relationship between science and society. From a speech, in some aspects, coincident with a kind of positivism, Skinner came to criticize purely formalist tendencies about scientific method, and from the defense of the management of society by experts, he came to a criticism of the centralization of power and to the proposal of a form of organization based on face to face control. Dealing with similar topics, Paul Feyerabend deconstructed the idea of a universal scientific method, denounced an oppressive potential of science, and claimed for scientific knowledge to have no inherent preference over other forms of knowledge to access to institutions of power. Considering the importance of both authors for the debates in the context of history and philosophy of science, this study aims to present and discuss aspects of Skinner's radical behaviorism and Feyerabend's epistemological anarchism that deal with common themes. We conclude that, although salient differences, both perspectives contain some convergent and virtually complementary propositions, whose dialogue could be useful to their pursuit of a free society.
\end{abstract}

Keywords: Philosophy of science, B. F. Skinner, Paul Feyerabend, Radical behaviorism, Epistemological anarchism.

\section{Skinner e Feyerabend sobre o Método e o Papel da Ciência em uma Sociedade Livre}

\section{Resumo}

Da obra de B. F. Skinner fazem parte preocupações de ordem epistemológica, encerrando discussões sobre metodologia e critérios de verdade, e outras de ordem política e social, concernentes à relação entre ciência e sociedade. De um discurso, em alguns aspectos, coincidentes com uma forma de positivismo, Skinner passou a crítico de tendências puramente formalistas sobre o método científico, e de uma defesa do gerenciamento da sociedade por especialistas, passou a uma crítica à centralização do poder e à proposta de uma forma de organização baseada no controle face-a-face. Tratando de temas semelhantes, Paul Feyerabend desconstruiu a ideia de um método científico universal, denunciou um caráter potencialmente opressor da ciência, reclamando que o conhecimento científico não deveria ter inerente predileção sobre outras formas de conhecimento para o acesso às instituições de poder. Considerando

Mailing address: Al. dos Narcisos, 235, Apto. 32C, Cidade Jardim, São Carlos, SP, Brazil 13566-534. E-mail: alvesdarocha@gmail.com

This text is the result of a final paper presented to the discipline "Introduction to the Philosophy of Science", attended by the author as a special student at the Postgraduate Program in Science, Technology and Society, of the Federal University of São Carlos. The author is a regular student of the Postgraduate Program in Psychology at the same university, and receiver of a PhD grant from the São Paulo Research Foundation (FAPESP), process 2014 / 02981-1. 
a relevância da obra de ambos os autores para debates suscitados no âmbito da história e da filosofia das ciências, este trabalho objetiva apresentar e discutir aspectos do comportamentalismo radical, de Skinner, e do anarquismo epistemológico, de Feyerabend, que tratam de temas comuns. Conclui-se que, apesar de diferenças salientes, as duas perspectivas contêm algumas proposições convergentes e virtualmente complementares, cuja interlocução poderia ser útil a seus objetivos de busca por uma sociedade livre.

Palavras-chave: Filosofia da ciência, B. F. Skinner, Paul Feyerabend, Comportamentalismo radical, Anarquismo epistemológico.

\section{Skinner y Feyerabend sobre el Método y el Papel de la Ciencia en una Sociedad Libre}

\section{Resumen}

De la obra de B. F. Skinner forman parte preocupaciones epistemológicas, incluyendo discusiones sobre metodología y criterios de verdad, y políticas y sociales, sobre la relación entre ciencia y sociedad. De un discurso, en algunos aspectos, coincidente con una forma de positivismo, Skinner pasó a crítico de tendencias puramente formalistas del método científico, y de una defensa de la gestión de la sociedad por los expertos, pasó a una crítica a la centralización del poder y a la propuesta de una forma de organización basada en el control cara a cara. Tratando con temas similares, Paul Feyerabend deconstruyó la idea de un método científico universal, denunció el potencial opressivo de la ciencia, y afirmó que el conocimiento científico no tiene preferencia inherente sobre otras formas de conocimiento para acceder a las instituciones de poder. Este estudio tiene como objetivo presentar y discutir aspectos del conductismo radical de Skinner, y del anarquismo epistemológico, de Feyeratend, que tratan de temas comunes. Llegamos a la conclusión de que, aunque las diferencias sobresalientes, ambas perspectivas contienen algunas propuestas convergentes y prácticamente complementarias, cuyo diálogo podría ser útil para los objetivos de la búsqueda de una sociedad libre.

Palabras clave: Filosofía de la ciência, B. F. Skinner, Paul Feyerabend, Conductismo radical, Anarquismo epistemológico.

B. F. Skinner (1904-1990) produced a large and complex body of work, which reflects the influence of several philosophical movements. Though Skinner was at first sympathetic to a sort of positivism in his view of science (cf. Skinner, 1938, p. 44), his ideas underwent continuous transformations over the course of his career (Moxley, 1998), culminating in a perspective far more similar to pragmatism and Darwinism (Laurenti, 2012). His political views, on the other hand, fluctuated throughout his career, from a nod toward technocracy all the way to a supposed tendency towards anarchy and direct democracy (Lopes, 2015). Freedom was also widely discussed by Skinner (1971), but his interpretation on the struggle for freedom made many considered him its enemy. These considerations cannot be easily integrated into a single, definitive Skinnerian response to the question: "what is the role of science in a free society?"

While this topic has been discussed by several philosophers and sociologists of science, some of the most noteworthy and provocative arguments on the subject were put forth by Paul Karl Feyerabend (1924-1994). Feyerabend $(1975 / 1993)$ deconstructed the canons of the "scientific method", denounced the potentially oppressive character of science, and cautioned against the prevalence of science as a threat to democracy (Feyerabend, 1978). The reaction to these positions was strident. Some criticized the way Feyerabend portrayed episodes in the history of science to support his ideas (cf. Sokal $\&$ Bricmont, 1998), while others went so far as 
to refer to him as "the worst enemy of science" (Horgan, 1993, p. 36).

However, a close analysis of the philosophical formulations of both aforementioned authors reveals that Skinner is no enemy of freedom, just as Feyerabend is no enemy of science. In spite of some clear differences, both authors made important contributions to several common themes. The aim of this article was therefore to present and discuss some topics in Feyerabend's epistemological anarchism and Skinner's radical behaviorism, exploring points of divergence and possible convergence between them. This approximation is justified by the relevance of both authors to the study of the role of science in society, as well as the innovative contributions of this ostensibly counterintuitive approach. While it may not be apparent at first glance, certain aspects of the work of each author complement each other, allowing for a comprehensive and conciliatory perspective which differs from those that originated it, but is nevertheless quite promising.

To this end, we will examine Skinner's and Feyerabend's positions on the scientific method, as well as their views on the relationship between science and society. This discussion will be presented in two parts. We will first identify possible points of convergence between the authors before exploring their divergences in a second section. These two sections will be followed by some brief final considerations.

\section{Points Of Convergence: For Science, Against Method}

Feyerabend was an Austrian philosopher, whose popularity began to rise in the 1970s with the publication of two major works on the philosophy and history of sciences: Against Method and Science in a Free Society, published in 1975 and 1978, respectively. He earned a doctorate in philosophy at the School of Economics, under the supervision of a key figure in the philosophy of science: Sir Karl Popper, who influenced Feyerabend in several different ways.

Popper was a rationalist and a liberal: his major work, The logic of scientific research, provides a detailed criticism of the canons of logical positivism, in addition to proposing and delineating a new logic for scientific research (based on conjectures and refutations), known as falsifiability. From an epistemological perspective, Popper's work is clearly prescriptive. Popper also addressed social and political issues in The open society and its enemies, in which he sharply criticized totalitarian and authoritarian governments.

In light of these findings, one might expect that Popper's anti-authoritarian tendencies would be reflected in Feyerabend's work, as is observed in the latter's obstinate criticism of the use of science as a source of power by authoritarian governments. However, such a consensus is not observed in the authors' discussions of rationalism. Although he was the first major critic of logical positivism, Popper (1959/1972) preserved and amplified the rationalist tendency by introducing the perspective of "critical rationalism", which describes a universal logic for the scientific enterprise, and allows for the possibility of purely objective knowledge, with the rationalist method paving the way for human development (cf. Marin, 2012).

As such, while Feyerabend may have been influenced by the liberal tendencies of his teacher, the two held radically different views of the primacy of reason and scientific knowledge, and of the relevance of these issues in a free society. This is clearly evident in the following excerpt from Against method: "Science is an essentially anarchic enterprise: theoretical anarchism is more humanitarian and more likely to encourage progress than its law-and-order alternatives" (Feyerabend, 1975/1993, p. 9). The author also notes that, while anarchism may not be the soundest possible basis for political philosophy, it may provide adequate solutions in epistemology by encouraging the critical questioning of essential canons of the scientific method.

Feyerabend (1975/1993) criticizes the notion of neutrality in favor of a historical rather than a merely formal perspective of the scientific enterprise:

Now it is, of course, possible to simplify the medium in which a scientist works by 
simplifying its main actors. The history of science, after all, does not just consist of facts and conclusions drawn from facts. It also contains ideas, interpretations of facts, problems created by conflicting interpretations, mistakes, and so on. On closer analysis we even find that science knows no "bare facts" at all but that the "facts" that enter our knowledge are already viewed in a certain way and are, therefore, essentially ideational. This being the case, the history of science will be as complex, chaotic, full of mistakes, and entertaining as the ideas it contains, and these ideas in tum will be as complex, chaotic, full of mistakes, and entertaining as are the minds of those who invented them. Conversely, a little brainwashing will go along way in making the history of science duller, simpler, more uniform, more 'objective' and more easily accessible to treatment by strict and unchangeable rules. (p. 11)

Despite the plurality of science, which follows naturally from the diversity of scientist minds, scientific activity will always tend to be simplified in the context of education, which will attempt to obliterate anything that escapes a purely rational reconstruction. This is what the author refers to as "brainwashing": the way in which scientific findings are taught and disseminated tends to propagate a particular ideal, which secures the superiority of this form of knowledge and its repercussions over all others. According to Feyerabend, this ideal permeates all scientific facts, which come to be conceived as entirely distinct from the contingencies which govern the actions of scientists.

Such movement would be responsible for the attempts to propagate the idea of a scientific tradition whose unity is guaranteed by the continued observance of "universal" methodological rules. Feyerabend (1975/1993), then, asks: is it desirable to support such a tradition? His answer, of course, is an emphatic "No", justified by the idea that scientific progress requires a certain degree of independence from methodological uniformity. This is where he offers his most controversial statement: "The only principle that does not inhibit progress is: anything goes" (p.
14).

Feyerabend (1975/1993) later appears to retract this statement, by describing it, rather than as a "principle", as the "terrified exclamation" of one who takes a closer look at history. Feyerabend supports his statement using several examples from the history of science, and especially, the history of physics:

... there is not a single rule, however plausible, and however firmly grounded in epistemology, that is not violated at some time or other. It becomes evident that such violations are not accidental events, they are not results of insufficient knowledge or of inattention which might have been avoided. On the contrary, we see that they are necessary for progress. Indeed, one of the most striking features of recent discussions in the history and philosophy of science is the realization that events and developments, such as the invention of atomism in antiquity, the Copernican Revolution, the rise of modem atomism (kinetic theory; dispersion theory; stereochemistry; quantum theory), the gradual emergence of the wave theory of light, occurred only because some thinkers either decided not to be bound by certain "obvious" methodological rules, or because they unwittingly broke them. (1975/1993, p. 14)

The latter concept, which refers to the unintentional violation of methodological rules, will play a major role in drawing parallels between the writings of Feyerabend and Skinner. Still in the context of Feyerabend, we must address his (almost redundant) insistence on the fact that these anarchic processes are not a feature of one particular science, or of certain isolated incidents, but a necessary prerequisite for general scientific development. Therefore, in addition to those cases in which scientists unwittingly violate methodological rules, there are times when they do so deliberately.

According to Feyerabend (1975/1993), a closer analysis of scientific development reveals several instances in the history of science in which rational arguments lose their anticipatory nature and become obstacles to scientific progress. When this happens, even self-proclaimed 
rationalists may turn to strategies foreign to formal scientific tradition. There are instances when Even the most puritanical rationalist will then be forced to stop reasoning and to use propaganda and coercion, not because some of his reasons have ceased to be valid, but because the psychological conditions which make them effective, and capable of influencing others, have disappeared. (p. 16) Yet if not even rational argument is safe, how could we argue that the concept of "anything goes" would lead to anything other than complete chaos and arbitrariness? The author addresses this issue by noting that science does follow some methodological patterns, models and norms, which will arguably always exist, but that these arise as a result of the research itself rather than from anticipatory and purely logical rationalizations. Therefore, the concept of "anything goes" should not be interpreted as a celebration of chaos in scientific practice, but rather, as a form of emphasizing the fact that all methodological rules must be developed based on the research situation, its context, and the information available at that particular point in time. Local and current circumstances must always be respected. In other words, there must be contingency. This is why rules must be constantly "reinvented", sometimes even in the form of "counter-rules", which are diametrically opposed to established methodological principles.

Examples of "counter-rules" which emerged from the "opportunistic" experiments of great scientists include counterinduction and ad hoc hypothesis, both of which run counter to the basic methodological principles of inductive reasoning and critical rationalism. A considerable part, if not all, of Feyerabend's work consists of detailed analyses of episodes in the history of science which gave rise to the aforementioned counter-rules, paying special attention to the physical sciences and to individuals such as Galileo Galilei (1564-1643) and Isaac Newton (1642-1727). However, it is important to note that Feyerabend does not make these observations in order to introduce a new, "anarchic" scientific methodology. According to the author himself, his goals are far more modest, and de- scriptive rather than prescriptive in nature:

One might therefore get the impression that I recommend a new methodology which replaces induction by counterinduction and uses a multiplicity of theories, metaphysical views, fairy-tales instead of the customary pair theory/ observation. This impression would certainly be mistaken [italics added]. My intention is not to replace one set of general rules by another such set: my intention is, rather, to convince the reader that all methodologies, even the most obvious ones, have their limits [italics added]. The best way to show this is to demonstrate the limits and even the irrationality of some rules which she, or he, is likely to regard as basic. (Feyerabend, 1975/1993, p. 23)

Having discussed Feyerabend's epistemological anarchism, we now move on to B. F. Skinner's behaviorism as we attempt to draw parallels between the two philosophies.

Skinner was an American psychologist and the founder of the philosophy known as radical behaviorism, on which he based his own scientific proposal: behavior analysis. His first publications described experiments with rats and pigeons, whose findings were used as a basis for the understanding of individual and social behavior in humans, and of cultural evolution from a selective perspective. However, over the course of the next six decades, his theoretical and methodological propositions underwent profound transformations (cf. Laurenti, 2012; Moxley; 1999). Several conceptions of science can be drawn from Skinner's descriptions of behavior analysis. The most notable is, perhaps, his definition of scientific knowledge as a form of verbal behavior: In the words of Skinner (1974), Scientific knowledge is verbal behavior, though not necessarily linguistic. It is a corpus of rules for effective action, and there is a special sense in which it could be "true" if it yields the most effective action possible. But rules are never the contingencies they describe; they remain descriptions and suffer the limitations inherent in verbal behavior. (p. 259)

Skinner recognized that the variables which 
control the behavior of scientists impose an insurmountable limitation on scientific knowledge, and as such, shifted away from representational perspectives in favor of a concept of truth which was similar to that offered by pragmatism. The rules of science, including all methodological guidelines, do not reflect contingencies as they are. They are simply descriptors, which guide effective human action.

The conception of science as verbal behavior raises additional questions. Which "limitations inherent in verbal behavior" are most relevant for the comprehension of science? And what would be the role of the scientific method in the production of knowledge according to this perspective? Skinner (1956) was concerned about these issues, and admitted that the science of behavior was unable to provide a satisfactory comprehension of scientific behavior in its current developmental state. The text from which this excerpt was taken may be the most appropriate for the present task of drawing parallels between the work of Skinner and epistemological anarchism. The work in question is $A$ case history in scientific method (Skinner, 1956). In this article, Skinner provides a humorous description of five key principles in an attempt to poke fun at the ideas of rigorous experimental control and strict observance of traditional methodological rules. Skinner's principles consist of the following: (a) When you run onto something interesting, drop everything else and study it, (b) Some ways of doing research are easier than others, (c) Some people are lucky, (d) Apparatuses sometimes break down, and (e) serendipity - the art of finding one thing while looking for something else.

Each of these principles is illustrated by important scientific discoveries, such as that of the cumulative recorder, the extinction curve, and reinforcement schedules, which led to the abandonment of the concept of reflex reserve. Interestingly, as he describes these principles, Skinner (1956) also notes (possibly in jest): "Since I do not wish to deprecate the hypothetico-deductive method, I am glad to testify here to its usefulness" (p. 226). Skinner makes this statement as he describes his own thought process prior to programming an intermittent reinforcement schedule for the very first time. This idea contradicts his previous rejection of the hypothetico-deductive method and ratification of inductive reasoning as the main research method in behavior analysis (e.g., Skinner, 1950, p. 215). In her assessment of the epistemology of radical behaviorism, Chiesa (1994/2006) writes: "While psychology students continue to be trained mainly in the formal methods of hypothesis testing and falsification, radical behaviorism is characterized by a less formal inductive approach" (p. 53).

Indeed, the way in which "hypothesis testing" inspired the episode described by Skinner is vastly different from that observed in the practice of scientists who use this as their main method of research: the Popperian method of conjectures and refutations does not apply at all to conventional research in behavior analysis. Nevertheless, this episode and others like it provide an important illustration of the 'hybrid' nature of Skinner's methodology: the descriptions and examples in A case history..., suggest that Skinner's own practical experience strays from the methodological rigidity prescribed by formalist approaches such as logical positivism and critical rationalism.

At this point, it is also important to consider the context in which $A$ case history... was published. At the request of the American Psychological Association, several renowned researchers published descriptions of the steps they followed in conducting their work. This initiative was referred to as Project $A$. According to Dutra (2004, p. 181), "the philosophical basis of Project A was clearly logical positivism". Skinner's text (1956) was a response to this project, and its contents argued directly against a perfectly logical and systematization of scientific practice. As a matter of fact, in its original context, Skinner's work may be conceived as a sort of subversive protest against the status quo of scientific methodology at the time:

Skinner is clearly attempting to subvert the order imposed by methodological theorists on experimental research. His five principles and corresponding examples were 
drawn from his first years as an experimental researcher, and appear to show that the contingency-based development of scientific research precludes the imposition of external methodological rules and standards.

(Dutra, 2004, p. 181)

Aware of the inherent limitations of verbal behavior, Skinner introduced his five "principles" (which were no more than recommendations drawn from his own laboratory experience) so as to alert others to the fact that only a greater understanding of human behavior could shed light on the most decisive aspects of science. The knowledge available at the time was still quite limited, and only its expansion would guarantee a better comprehension of the scientific process: "We do not know enough about human behavior to know how the scientist does what he does" (p. 221). Interestingly, while Skinner's (1950) views on the primacy of inductive reasoning and single-subject designs may contrast with the non-prescriptive tendencies of Feyerabend, Skinnerian behaviorism, like epistemological anarchism, agrees that science could never be fully explained simply by the formal systematization of its methods.

Skinner (1956), like Feyerabend (1975/1993), appears to be more concerned with the limitations of the current model and the need to caution against its universalization, than with developing a methodological alternative: "When we have at last an adequate empirical account of the behavior of Man Thinking, we shall understand all this. Until then, it may be best not to try to fit all scientists into any single mold [italics added]" (Skinner, 1956, p. 233).

\section{Points of Divergence: The Role of Science in a Free Society}

In his work 'Science'. The myth and its role in society, Feyerabend (1975) raises questions which go beyond the scope of epistemology, and address some of the issues discussed in the sociology of science. This is where he presents some of his most controversial claims, which he would only elaborate three years later, with the publication of Science in a free society. One of the issues discussed by Feyerabend (1975) is the relationship between science and state, or, more specifically, between educational processes and scientific teaching:

A science that insists on possessing the only correct method and the only acceptable results is ideology and must be separated from the state and especially from education. ... A mature citizen is not a man who has been instructed in a special ideology, such as Puritanism or critical rationalism, and who now carries this ideology with him like a mental tumor. A mature citizen is someone who has learned how to make up his mind and who has then decided in favor of what suits him best. He is a person who has a certain mental toughness (he does not fall for the first ideological street singer he happens to meet), and who is therefore able to consciously choose the business that seems to be most attractive to him, rather than be swallowed up by it. To prepare him for his choice, he will study the major ideologies as historical phenomena, he will study science as an historical phenomenon and not as the one and only sensible way of approaching a problem. He will study it together with other fairytales, such as the myths of "primitive" societies, so that he has the information needed for arriving at a free decision. An essential part of a general education of this kind is acquaintance with the most outstanding propagandists in all fields, so that the "pupil" can build up his resistance to all propaganda, including the propaganda called "argument". It is only after such a hardening procedure that he will be called upon to make up his mind on the issue rationalism-irrationalism, science-myth, science-religion, and so on. Any decision made in this way will be far more "rational" than any other decisions purportedly made in favor of science today. (pp. 175-176)

Feyerabend's defense of a historical perspective in scientific teaching reveals that he is no enemy of science, but also shows us why some are intent in referring to him as such. Feyerabend (1975) simply states that science should 
be taught from a historical standpoint, and that none of its inevitable embarrassments should be hidden from view. On the contrary, contingencybased and human aspects of knowledge production must be emphasized, and that the idea of an ideal method or a single model of scientific thinking must be abandoned.

A historical approach to science, whereby the subject is taught based on tangible episodes, described in full detail, peculiarities and all, would challenge the establishment idea of a universal scientific method. Feyerabend states that science should be taught as is: "embodied" by scientists, contaminated by idiosyncrasies, historically situated, and inevitably influenced by circumstance. Those who are too attached to traditionalist tendencies in modern science would certainly frown at the prioritization of contingency over universality, and of historicity over unconditionality, which may at least partly explain the negative reactions to Feyerabend's proposals.

But that is only part of the controversy: not only does Feyerabend (1975) claim that science should be taught from a historical standpoint, but also that it should be placed on equal ground with other sources of knowledge, with no a priori advantage over other ways of knowing. After being introduced to both scientific and non-scientific approaches to the "same" or "analogous" phenomena, individuals would be much better prepared to compare, assess and deliberate over the type of explanation which suits them best. Interestingly, Feyerabend (1975) defends the coexistence of science and non-science in the context of education precisely to ensure that those who choose science do so in a rational manner, based on the advantages of scientific explanations over less reasonable perspectives. Only when science is placed on equal grounds with other forms of knowledge will individuals have a fair and legitimate chance to choose a scientific explanation with conviction, believing that its virtues are somehow better, superior, more convenient or more effective in addressing the needs they feel to be relevant.

In this sense, epistemological anarchism approaches current trends in contem- porary pragmatism, which criticizes the notion of "privileged discourses". This tendency is perhaps best described by Rorty (1998), a philosopher who reformulated classical pragmatism and claimed that: "science, religion and the arts are all, equally, tools for the gratification of desire. None of them can dictate, though any of them can and will suggest, what desires to have or what evaluative hierarchies to erect" (p. 199). Feyerabend (1975/1993) criticizes the unconditional privilege of scientific rationalism in a free society, and goes so far as to mention a "pragmatist philosophy" in the following excerpt:

A society based on rationality is not entirely free; one has to play the game of the intellectuals. An open exchange, on the other hand, is guided by a pragmatic philosophy ... An open exchange respects the partner whether he is an individual or an entire culture, while a rational exchange promises respect only within the framework of a rational debate. (pp. 227-228)

It is difficult to read Feyerabend's work without considering the practical and social implications of epistemological anarchism. How could his suggestion that science be separated from state to the same degree as religion is (or should be) influence life in society? As for scientific teaching, Feyerabend does not advise its exclusion from curricula, but suggests that it be taught together with other forms of knowledge, emphasizing rather than hiding its methodological plurality and limitations. That is, any accidents, mistakes and unforeseen circumstances should be openly discussed, and science should not be conceived as a superior and methodologically monolithic source of knowledge.

Another important repercussion of epistemological anarchism is the change in dynamics between specialists and lay people. Expert opinion is often prejudiced and not subject to control by forces outside of science itself. This is an especially relevant concern in the case of politics, where state and science often form alliances in which political proposals derive credibility from expert proponents. This approach is often justified by the idea of unanimity: the scientific com- 
munity, which tends to converge on unanimous decisions, would appear to provide a stronger basis for political action.

Feyerabend (1978) responds to this argument by noting that unanimity is often the result of political, rather than scientific, intervention:

Unanimity is often the result of a political decision: dissenters are suppressed, or remain silent to preserve the reputation of science as a source of trustworthy and almost infallible knowledge. On other occasions, unanimity is the result of shared prejudices: positions are taken without detail examination of the matter under review and are infused with the same authority that proceeds from detailed research. (p. 88)

How then to proceed? If political decisions are not to be based on science, on what should they be based in its stead? In a world fraught with dramatic social issues, it seems counterintuitive to foment suspicion against scientists who are only looking for possible solutions. However, Feyerabend (1978) does not believe that science and rationality should be entirely excluded from the political realm. Science should not be destroyed, only stripped of its privileged status. This would place science on equal competitive footing with other forms of knowledge, granting equity of access to institutions of power.

Feyerabend (1978) also recommends that science be supervised by lay people who evaluate its legitimacy. According to the author, the lay people troubled by the issues which science aims to resolve are the most interested party in scientific development, and as such, should have the right to supervise its practices. The supervision of science by lay people could occur in several different ways:

Duly elected committees of laymen must examine whether the theory of evolution is really as well-established as biologists want us to believe, whether being established in their sense settles the matter, and whether it should replace other views in schools. They should examine the safety of nuclear reactors ... whether scientific medicine deserves the unique position of theoretical authority ... The committees must also ex- amine whether peoples' minds arc properly judged by psychological tests, what is to be said about prison reforms and so on and so forth. In all cases the last word will not be that of the experts, but that of the people immediately concerned. (Feyerabend, 1978, pp. 96-97)

One of the most common arguments against this proposition is that it detracts attention from a bigger issue, which is the need to instrumentalize lay people (by providing them with science education) so then, and only then, they would be able to perform a legitimate assessment of scientific knowledge. Feyerabend (1978) was not unaware of this argument. However, he believed that the instrumentalization of lay people would result in the propagation of traditional values which proclaim and reinforce the superiority of science. To assume that lay people are unable to perform this sort of judgment is to accept the idea that only intellectuals have a legitimate right to power. To an epistemological anarchist, that is the exact opposite of a free society.

Feyerabend (1975/1999), defines science as an "intellectual discipline that can be examined and criticized by anyone who is interested, and that looks difficult and profound only because of a systematic campaign of obfuscation carried out by many scientists" (p. 187). According to this perspective, democracy must be expanded to eliminate the possibility of monopolistic or privileged access to scientific knowledge. Egalitarian decision making and the radicalization of democratic practices will prevent science from taking on the role of a tribunal for politics and politicians. The most desirable virtue from this point of view, rather than perfect rationality, is what Feyerabend (1978) refers to as maturity. The author defines the concept as follows: "The maturity I am speaking about is not an intellectual virtue [italics added], it is a sensitivity [italics added] that can only be acquired by frequent contacts with different points of view" (p. 107).

As we move on to behaviorism, one might wonder: How could we possible articulate Feyerabend's extravagant ideas with Skinner's thoughts on the role of science in a free society? As previously stated, the political contents in 
the work of Skinner can be interpreted in several different ways. One of these interpretations is diametrically opposed to the views of Feyerabend (1978), and consists of a compliment to technocracy, a government composed of technicians, which leaves experts entirely in charge of all decision-making. This is precisely the type of reality portrayed in the Utopian novel Walden two (Skinner, 1948), which depicts a society in which a group of "planners" are entirely in charge of all political deliberation, leaving little room for popular participation and the lay community.

However, it is important to note that, according to Skinner $(1948,1969)$, Walden two describes an idealized egalitarian society, where citizens only work for a few hours a day, and even then, only voluntarily, the arts and sciences flourish, and all forms of exploitative control have been completely abolished. To ensure the ideal functioning of the community, all political power is concentrated in the hands of specialists, who are responsible for the "experimental management" of the local culture in the utopian search for a better world. Skinner (1948) provides a somewhat unusual justification for the absence of popular participation in this scenario, which is explained by the character Frazier, one of the "planners":

The people are in no position to evaluate experts ... The amateur doesn't appreciate the need for experimentation. He wants his expert to know. And he's utterly incapable of sustaining the period of doubt during which an experiment works itself out. The experts must either disguise their experiments and pretend to know the outcome in advance or stop experimenting altogether and struggle to maintain the status quo. (Skinner, 1948, p. 251)

It could be argued that Walden two is only a novel, and as such, may not provide a reliable picture of Skinner's philosophical positions. However, these arguments can be addressed by statements made by Skinner himself, who said of his novel that "some readers may take the book as written with tongue in cheek, but it was actually a quite serious proposal" (Skinner, 1969, p. 199), and that "Frazier's views are essentially my own - more so now than when I first wrote them" (1983/1984, p. 9).

These observations provide some relevant information on Skinner's views of the role of science in society, and especially in politics. One possible interpretation of Skinner's work (1948) is that the author believes that science and scientists should have a privileged position in society, preferably as the managers or, more precisely, the planners, of popular culture. The conclusion that experts should be entirely responsible for political deliberation, and that the lay people should be entirely excluded from this process, is the opposite of that drawn by Feyerabend (1978).

However, an alternative interpretation of Skinner's political views can be derived from Human behavior and democracy, published nearly three decades after Walden two. In this work, Skinner (1978) critiques representative democracy, and appears to make the case for a social organization system based on what he refers to as "face to face control". According to the interpretation of some scholars, such a system would be more similar to direct or participatory democracy and may arguably reflect some anarchist tendencies. This is a radically distinct perspective from that presented in the society described in Walden two (cf. Lopes, 2015). As Skinner describes his proposed societal organization, he also criticizes the concentration of power, as can be seen in the following excerpt: "Concentration of power in an agency is objectionable not only because it is characteristically misused and wasted but because it destroys interpersonal contacts" (Skinner, 1978, p. 9).

Skinner's (1948) defense of the management of popular culture by a group of specialists who hold all political power contrasts sharply with his warning against the concentration of power in a single agency because it would be continually misused (1978). What is the reason for these inconsistencies? It is possible that, in Skinner's perspective, unlike government, religion, education, psychotherapy and economics - all of which are described as controlling agencies of human behavior (Skinner, 1953/2005) - 
science is not just another agency. The use of science for good or evil is beyond the scope of the subject itself: the problem is not the science per se, but some of its applications.

If this is the case, Skinner's analysis $(1953 / 2005)$ of the control exerted by some of these agencies could be seen as a way in which scientific knowledge can be used to challenge abuses of power. Science could serve both the government and the governed, since its nature is neither libertarian nor despotic. The governed may use the science of behavior to understand how they are controlled by different instances of power, and, if necessary, engage in the countercontrol strategies cited by Skinner (1953/2005), such as escape, revolt or passive resistance. In this way, the knowledge provided by behavior analysis may allow for the comprehension and deconstruction of oppressive contingencies, both of which are crucial in the struggle for freedom.

\section{Final Considerations}

The 20th century saw the coexistence of several different perspectives on the nature of science and the scientific method. The first few decades saw the establishment of logical positivism, which was then progressively supplanted, especially in the second half of the century, due to the criticisms leveled by Popper (1959/1972), and the historically-oriented epistemological perspectives which followed it, such as that of Feyerabend (1975/1993). In the meantime, B. F. Skinner dedicated himself to the development of a science of behavior, before engaging in more general discussions of science and the scientific method. Skinner (1956) raises some issues that would manifest later in radicalized form in traces of Feyerabend's epistemological anarchism.

In this way, Skinner (1956) can be seen as something of a pioneer, since, at the time of his writing, logical positivism was still significantly influential, as critical rationalism gained in strength. Skinner and Feyerabend differ on several aspects of their perspectives. Though the former was a staunch empiricist, he could not possibly endorse Feyerabend's exasperated attacks on rationalism. Similarly, in the perspective of the latter, Skinner's discourse, though often critical of formalism, would never be considered subversive enough to provide a basis for epistemological anarchism. Nevertheless, in spite of these obvious differences, both authors made significant contributions to our conception of the scientific enterprise based on practical, and historically-situated experience, characterized by an epistemology that is less formalist and universal, and more contingency-based in its underpinnings.

The role of science in a free society is the topic of greatest disagreement between Feyerabend and Skinner. For the former, in a free society, not only should science be placed on equal grounds with other sources of knowledge (both in the education and political arenas), but it should also be supervised by lay people. Skinner, on the other hand, fluctuated between technocratic and pro-anarchist perspectives, sometimes recommending that science be given special emphasis in political deliberation and that power be concentrated in the hands of specialists, and other times presenting an optimistic view of science as a method of countercontrol and, consequently, an important instrument in the struggle for freedom.

In conclusion, we note that, although at first glance they may seem to present extreme and radically antagonistic views, Skinner and Feyerabend's perspectives can be seen as complementary. Skinner proposes an "experimental attitude" in politics, but cautions against the concentration of power. As such, it may be interesting to consider forms of allowing for government experimentation while mitigating the risks associated with concentrated power.

This mitigation may be achieved by Feyerabend's (1978) suggestion of duly elected committees of lay persons tasked with the supervision of scientific efforts. Such a proposal would lead to the abandonment of Skinner's initial recommendations (1948) regarding the exclusive rights of specialists over culture planning. The legitimacy of planning mechanisms would then be decided only by those who are directly involved in the 
issues at hand. In this way, Feyerabend's proposition may address Skinner's silence on the role of science as a controlling agency.

Additionally, Feyerabend's identification $(1975 / 1993)$ of a close historical relationship between progress and methodological pluralism could serve as a basis for Skinner's idea of culture planning. Galvanized by an anarchicepistemological attitude, the empirical character of culture planning could be vastly emphasized, by submitting several procedures to scientific experiment, ensuring and expanding its plurality, and even turning to procedures, methods and techniques derived from sources other than science. In this way, Skinner's (1974) tendency to define truth in terms of effectiveness rather than its representational qualities may converge with the pragmatist tendencies of Feyerabend $(1975 / 1993)$, who refuses to let science take the place of a privileged discourse. The complete exclusion of scientific input in the planning of life in society, which may be inferred from Feyerabend's work (1978), could be revised in light of Skinner's (1971) observations in favor of deliberate cultural planning.

The propositions offered in this work are undeniably controversial, and could not be fully supported by the work of either author alone. Nevertheless, it can be deemed as a promising perspective precisely because it considers the most interesting aspects put forth by both authors, such as Skinner's behaviorist experimentalism and Feyerabend irreducible pluralism.

The way in which such a proposal would be put into practice is yet to be investigated. A coalition between behaviorist experimentalism and anarchic-epistemological pluralism could lead to both unexpected and unpredictable consequences. However, these ideas appear to form a promising alliance, prompted by a noble objective: the hope that the search for a better world does not obstruct our path to a free society.

\section{References}

Chiesa, M. (2006). Radical behaviorism: The philosophy and the science. Boston, MA: Authors Cooperative. (Original work published 1994)
Dutra, L. H. A. (2004). Behaviorismo, operacionalismo e a ciência do comportamento científico. Philósophos - Revista de Filosofia, 9(2), 179206. doi:10.5216/phi.v9i2.3035.

Feyerabend, P. K. (1993). Against method. London: Verso. (Original work published 1975).

Feyerabend, P. (1999). How to defend society against science. In J. Preston (Ed.), Paul K. Feyerabend: Knowledge, Science and Relativism: Philosophical Papers Vol. 3 (pp. 181-191). Cambridge, MA: Cambridge University Press. (Original work published 1975).

Feyerabend, P. (1975). 'Science'. The myth and its role in society. Inquiry, 18(2), 167-181. doi: $10.1080 / 00201747508601758$

Feyerabend, P. K. (1978). Science in a free society. London: Verso.

Horgan, J. (1993, May). Profile: Paul Feyerabend The Worst Enemy of Science. Scientific American, 36-37.

Laurenti, C. (2012). O lugar da análise do comportamento no debate científico contemporâneo [The place of behavior analysis in the contemporary scientific debate]. Psicologia: Teoria e Pesquisa, 28, 367-376. doi:10.1590/S010237722012000300012 doi:10.1590/S010237722012000300012

Lopes, C. E. (2015). The political discourses of behavior analysis. Operants, 27-32.

Marin, S. R. (2012). Intervenção social e desenvolvimento humano em Karl Popper. In P. E. Oliveira (Ed.), Ensaios sobre o pensamento de Karl Popper (pp. 252-273). Curitiba, PR: Círculo de Estudos Bandeirantes.

Moxley, R. A. (1998). Why Skinner is difficult. The Behavior Analyst, 21(1), 73-91.

Moxley, R. A. (1999). The two Skinners, modern and postmodern. Behavior and Philosophy, 27, 97-125. Retrieved from http://www.jstor.org/ stable/27759395

Popper, K. R. (1972). A lógica da Pesquisa Científica (L. Hegenberg, \& O. S. da Mota, Trads). São Paulo, SP: Cultrix. (Original work published 1959)

Rorty, R. (1998). Truth and progress: Philosophical papers III. Cambridge: Cambridge University Press. 
Skinner, B. F. (1938). The behavior of organisms. New York: Appleton-Century.

Skinner, B. F. (1948). Walden two. New York: Macmillan.

Skinner, B. F. (1950). Are theories of learning necessary? Psychological Review, 57, 193-216. doi:10.1037/h0054367

Skinner, B. F. (1956). A case history in scientific method. American Psychologist, 11, 221-233. doi:10.1037/h0047662

Skinner, B. F. (1969). Contingencies of reinforcement: A theoretical analysis. New York: Appleton-Century-Crofts.

Skinner, B. F. (1971). Beyond freedom and dignity. New York: Pelican Books.

Skinner, B. F. (1974). About behaviorism. New York: Alfred A. Knopf.

Skinner, B. F. (1978). Human Behavior and Democracy. In Reflections on Behaviorism and Society (pp. 3-15). Englewood Cliffs, NJ: Prentice Hall.
Skinner, B.F. (1984). A matter of consequences: Part three of an autobiography. New York University Press. (Original work published 1983)

Skinner, B. F. (2005). Science and human behavior. B. F. Skinner Foundation. (Original work published 1953). Retrieved from http://www.bfskinner. org/newtestsite/wp-content/uploads/2014/02/ ScienceHumanBehavior.pdf

Sokal, A., \& Bricmont, J. (1998). Fashionable nonsense: Postmodern intellectuals' abuse of science. New York: Picador.
Recebido: 04/01/2016

$1^{a}$ revisão: 13/04/2016 Aceite final: 29/04/2016 